\title{
Comparison of satisfaction with happiness in families with children between the Czech- Latvian people
}

\author{
L. Stasova ${ }^{1}$ and L. Vilka ${ }^{2}$ \\ ${ }^{1}$ University of Hradec Kralove, Czech Republic \\ ${ }^{2}$ Riga Stradins University, Latvia
}

\begin{abstract}
It is an assumed opinion that the family is the main unit of society. The society and the family are in reciprocal influence: the healthier the families are, the healthier the society and vice versa. Subjective wellbeing and satisfaction with life are important factors in family stability. Feeling of happiness and the image of a happy family in contemporary Czech and Latvian society are the focus of the research. In the research the data from an international survey on the lifestyle of contemporary families that have been collected during 2013-2014 in the Czech Republic and Latvia were used. A self-administered questionnaire data were collected in both countries as well. A mixed approach with emphasis on the quantitative approach to research was used in data analysis. The results showed a significant similarity, although the "feeling of happiness" differed and varied in each specific family. So it was possible to use the same categories of "a happy family" that had been found in both samples of data (Czech and Latvian) material, and they were: financial prosperity, good relationships and success in the family, cohesion within the family, doing things and spending leisure time together and a healthy family.

The research results allow us to conclude that the family has a high value in people's minds despite the rapid changes in the family structure and de facto high rate of divorce in both countries.
\end{abstract}

Key words: family, happiness, happy family, lifestyle.

\section{Introduction}

Family is a unique entity in a society and a basic unit with the reciprocal impact on many processes in a societal development dynamics. Due to the reciprocity effect family studies are important for economic and welfare policy strategies in the country.

In this research we use the concept of family as a relatively stable social group with adults dealing with household and caring for children.

Advantage of having families can be seen not only on the societal level but also in everyday life of its members. Everyday life we understand as consisting of provision of daily needs, routine work activities and leisure time, inner family self-organization and in social relationships within the environment. 
Family capacity to deal with routine, solve problems and difficult situations indicates the stability of the family as the social institution.

One of the important and strengthening moments in family life is a feeling of happiness and satisfaction which brings a feedback to family members and improves their cohesion and activity.

Happiness is a multi-sided subjective category. Feeling of happiness depends on the idea about the source of happiness and different contexts: material wellbeing, emotional wellbeing, self-fulfillment and career, connectedness and ties with friends, healthy family, etc.

In particular, happiness questions are increasingly used in population surveys and it is suggested that a new science of happiness is emerging which aims to measure happiness, identify the main factors affecting it and quantify their relative importance [1].

In the Czech Republic, research related to the life satisfaction has been focused mainly on the psychological aspects of happiness (e. g. Kožený, Csémy, Tišanská, 2007 [2], Sobotková, Reiterová, Hurníková, 2011 [3]. and links between the family status and family environment and happiness (e.g. Hamplová, 2006 [4]). In the analysis of 21 European countries Hamplová tested assumption regarding family status and happiness in life. Different previous surveys had declared that married people live longer and have a lower probability of death, suffer less from mental diseases, they are more healthy, happy and satisfied in their lives. Hamplová confirmed these hypothesis by the European data $[5]^{1}$ positive influence of marriage and partnership can be explained not only by a better health status and financial situation of families in comparison with people living alone, but with high probability, it could be supported by better understanding, support, help and stimulation in the family environment.

Researcher's interest on subjective wellbeing of the inhabitants has raised also in Latvia during the last ten years. Studies on life satisfaction and feeling of happiness mainly have been done in the context of welfare studies from different perspectives. But two studies deserve special attention as they are focused on this specific field: The structure of Latgale inhabitants feeling of happiness and content of psychological well-being. The thesis for obtaining Doctoral degree in Psychology (Eriks Kalvāns (2013)) and Comparative analysis of subjective well-being of Latvia's inhabitants in the context of economic development of the Baltic States (Jelena Lonska (2015)).

To be happy in a family brings for the family members strength to overcome troubles in their jobs, in unemployment, in illness, and different types of losses.

What prerequisites people need to be happy? What does it mean to be happy in a family? How the idea of happiness in people's mind is constructed? What components create a satisfaction in family life? How happy are families with children today?

These questions we try to follow in this paper. We used the data from an international survey on the life style of contemporary families that have been collected during 20132014 in Czech Republic and Latvia.

A self-administered questionnaire was translated from Czech to Latvian and data were collected in both countries. Our questionnaires contained items related to specific areas of life style. This text is only concerned with data regarding perceived happiness and satisfaction within families. The data came from what the respondents declared, and are therefore as reliable as the honesty of their answers. It should be also declared that the main idea of our study was not focused on the welfare and happiness in family but followed a life style of family as a whole concept. From this reason our questions related to happiness could create only a small part of our questionnaire and could not be studied in their broader context.

\footnotetext{
${ }^{1}$ Unfortunatelly Latvia has not been included in this study.
} 
Despite complications related to the methodology used, and the sample obtained in both countries, we try to compare basic trends and show aspects of the life styles of contemporary families in a new light.

\section{Family in the Czech Republic and Latvia}

For starting this comparative research we find it useful to get a general view on the happiness as the study object in both countries. As the relative point of reference for measuring the feeling of happiness can be used the ranking of happiness in The World Happiness Report (2016) [6].

Ranking of Happiness 2013-2015 (Part 1) shows quite big interval between Czech Republic and the Baltic States: placing Czech Republic (6.596) in the 27th position following Lithuania (5.813) in the 60th position, Latvia (5.560) in the 68th position and Estonia (5.517) in 72nd position [6].

The feeling of happiness is not static. During the period from 2005-2007 to 2013-2015, more rapid dynamics in changes of happiness was observed in Latvia (0.872) placing it in the 5th position into the ranking of the changes. While in Czech Republic dynamics in the changes of happiness were slowlier - Czech Republic (0.126), 55th position in the ranking of changes.

The differences can be explained by the transformations in the context of life. During this period Latvian people felt themselves particularly inspiring and enthusiastic, because Latvia in 2004 became the member state of EU.

European families differ in many ways, although some trends overcome boarders and could be found in every country at the different level.

Current trends among Czech families are demonstrated by a number of specific features [7]. Firstly, Czech families tend to have lower stability, which is expressed by a high divorce rate. Statistical data support this long-lasting trend. In recent years, the divorce rate has oscillated at about $50 \%$, which means that half of all marriages fail.

Contemporary Czech spouses can finish their relationships relatively easily, especially when there are no dependent children in the family, and tend to solve interpersonal problems by leaving the partnership. Moreover, the lower stability of partnerships and families has a big impact on children.

More than half of them experience the divorce of their parents (in $56.9 \%$ of divorces there were dependent children), and the majority live with a new partner of their mother/father.

Secondly, Czech families are less and less based on formal marriage. Young people perceive that marriage is not necessary for a happy partnership, and that marriage can ever destroy a healthy relationship. These trends are documented in statistical evidence which shows a decrease in the marriage rate and an increase in the number of cohabitating couples. According to the current level of first marriage rates, only slightly more than $50 \%$ of people enter marriage during their life. In relation to both trends mentioned above, a growing number of Czech children are born out of marriage $(47.3 \%)$, but this does not mean that they do not live in a two-parent family.

The age of parenthood in the Czech Republic is increasing, and now most mothers give birth at the age of 30, the average is 29.9 .

Generally, contemporary parents wait for a stable professional position and a convenient economic level before having children. Young people declare that good housing and salaries are important preconditions for creating a family. However, family/ work competition often continues much further, because Czech families need two working adults who secure the economic stability of the family. This pushes many mothers to spend a lot of time at work even if they have small children. 
Part-time jobs in Czech are unusual and the labour market does not offer enough possibilities for contemporary parents to balance their families and careers. Generally, this means less time for family activities, children and partners. It is possible to observe growing difference among families related to their financial situation, material wealth and lifestyle.

Czech families are also based on liberal relationships, primarily at the parents/child level. In relation to the decreasing number of children in families (the average is 1.4 children per mother), children's position in the family has increased, giving them more opportunities for discussion and negotiation, which can influence what the family does.

Latvian families were represented by the number 588000 according to the census in 2011. 54\% of them consisted of married couples with children, $29 \%$ were single mother families, $4 \%$ are single father families and $13 \%$ are unmarried couple families. The most represented group of families - married couple families - had one child $40 \%, 2$ children in $22 \%$ and $3+$ children $-6 \%$. The cohabited families had in $35 \%$ one child, 2 children in $18 \%$ and $3+$ children in 7\%; Single mother families had a structure - family with 1 child $-75 \%$, 2 children $-20 \%, 3+$ children $-5 \%$; Single father families have 1 child $-82 \%, 2$ children $16 \%, 3+$ children $-2 \%[8]$.

In 2011 in Latvia were fixed 10760 marriages and 8302 marriages were divorced. Crude marriage and divorce rates were 5.2 and 4.0 (per 1000 inhabitants).

In 2011 in Latvia 18825 babies were born: it is 9.1 per 1000 inhabitants. The highest birth rates are for women at the age $25-34-58 \%$. 434 babies were twins in the families [9].

Family situation in Latvia has strongly been influenced by financial-economic crisis.

It should be noted that at the beginning of 2015 the population declined to 1.99 million [CSP, Demography 2015, 21] and, accordingly, calculations were made, with the assumption that the average family size remained the same as in the 2011 Population Census, it was concluded that at the beginning of the year 2015 the number of families has decreased to 565 thousand, or $10 \%$ compared to 2000 [10].

\section{Life style of family and happiness in family life}

\subsection{Methodology of a survey}

Joint research - life style of the contemporary family

\section{Our questions were aimed at:}

- What is an image of happiness in family?

- What creates a feeling of being happy with family life?

- Satisfaction in family life related to the free time activities?

- What are the differences between Czech and Latvian families?

We used a mixed approach with the stress on the quantitative one. We prepared a questionnaire with some open questions for a qualitative analysis. Our samples in both countries were created by families with children in the age $0-17$.

The Czech sample was composed of 1308 families. More than half of them (51.8\%) had two children, about $28 \%$ had one child, $11.6 \%$ had three children, and slightly more than $3 \%$ had four or more children or they did not have children. The age of parents ranged from 20 to 56, and the age differences between spouses were not enormous. Adult occupations varied from unskilled, low-paid positions to highly specialized, well-paid positions. 24.4$25.7 \%$ of our respondents (male and female) had a university degree.

The Latvian sample was composed of 383 families from different regions and local communities. $32 \%$ of them have 1 child, $42 \% 2$ children, $15 \% 3$ children, $7 \% 4$ children, 
$3 \% 5$ children, $1 \% 6$ children. The age of family members who represented family ranged from 28 to 74 .

The old age of respondents is explained with the high number of emigrated families in hope to find a better paid job abroad, who leave their children with their grandparents or other relatives.

There are families who after being abroad take their children abroad as well.

Adult occupation varied from unskilled, low-paid positions to highly specialized ones. $16.5 \%$ of our male respondents and $15.5 \%$ of females had a university degree. Data were collected from 21 region centers and towns in Latvia, excluding Riga, the capital of Latvia. The women education level in Latvia comparing with men education level is higher.

Table 1. The data collected in 2014.

\begin{tabular}{|l|c|c|}
\hline & Czech Republic & Latvia \\
\hline Number of interviewed families & 1308 & 383 \\
\hline No. of children -1 & $28.9 \%$ & $32.5 \%$ \\
\hline No. of children -2 & $55.0 \%$ & $41.8 \%$ \\
\hline No. of children -3 & $12.3 \%$ & $15.2 \%$ \\
\hline No. of children $-4+$ & $3.8 \%$ & $10.5 \%$ \\
\hline
\end{tabular}

\subsubsection{What is your image of a happy family?}

In the first group of answers in our questionnaire, there were some open items used that were completed by the respondents in their own expressions.

One of these items was a description - what is your image of a happy family? Afterwards, we used the qualitative analysis and identified four groups of answers. The analysis was made separately in the Czech Republic and Latvia.

Subsequently, we put our results together and realized that our results showed a significant similarity, in spite of the "feeling of happiness" differs and vary in concrete family. Because of that we could use the same categories that had been found in both samples of data (Czech and Latvian)

Categories of "a happy family"

1. material and financial prosperity

2. good relationships and success in the family

3. family cohesion, doing things and spending of leisure time together

4. healthy family

These categories in many correspond also to some authors' viewpoint on prerequisites' of happiness:

"A happy life involves prerequisites, particularly external prosperity. Aristotle mentions, for example, health and food (McKeon, 1947; Ross, 1925). We would like to add that fundamental to health, in modern Western living, is access to medical care, if and when needed, sanitation, transportation, and education, among other factors."; Money is not an end as such, but rather a tool with which a happy life can be enhanced (McKeon, 1947; Ross, 1925; Tabensky, 1998) Sharing pleasures can be regarded as an initial path to happiness; stable relations seem to contribute, in general, to feelings of happiness in spouses/co-habiters and children (Hetherington \& Koch, 2002; Paul, 2002) [11].

In the answers of respondents in both research samples we could find a strong category that was fed by such expressions like - happy family needs to have enough money, good housing, good job of parents, assurance of employment, no debts, etc.; 
Respondents declared in their statements, that for them it is important to have money, good housing, get a good job and have a stability of employment to feel the happiness in family life.

These conditions, mostly from the external environment, showed how important is for family members the family policy supporting basic needs of different family types. These aspects can be guaranteed by the state and its policy.

Second group of answer surrounded family relationships and included feeling of love, friendship, tolerance, reliability, respect, good communication, trust and responsibility. These internal aspects show that processes within the family are very important to be happy in the family. People expect to find love, friendship and reliability in the family environment and to have a safe space for their everyday life that they can rely on.

Third category of answers has been saturated with expressions of cohesion, doing things together and spending leisure time of family together. Being together as a group, feeling of collective spirit and belonging to it has inspired some respondents to find their happiness in these issues. This category could be understood as an active dimension of family life and happiness in it.

Our respondents declared that they feel happy in the family when they can do things together with other family members. This "active group belonging" supports positive relationships and creates a cohesive climate in families.

The last category in our data has showed that health of family brings another dimension to happiness. Not to feel sickness, not to face sickness of any member of the family means an important determinant in possibility to feel happy in family. This factors lies mostly out of the decision of family members as an external factor. Social and health policy can only support a development of different preventive activities to avoid the most common diseases and civilization illnesses.

What we could add to this categorization is, that in some cases respondents did not answer this question or declared that happy family was their family.

After this qualitative analysis in both samples that has revealed most important pillars of happiness and satisfaction in family we came to the quantitative analysis of our data. From this point of view, for Czech respondents, happiness was mostly linked to a health of family (51\%), harmonic relationship (36\%) and financial prosperity (43\%).

Table 2. Happiness and satisfaction.

\begin{tabular}{|l|c|c|}
\hline & $\begin{array}{c}\text { Czech } \\
\text { Republic (\%) }\end{array}$ & $\begin{array}{c}\text { Latvia } \\
\mathbf{( \% )}\end{array}$ \\
\hline Health (category 4) & 51.2 & 45.6 \\
\hline Good living (category 1) & 7.2 & 3.2 \\
\hline Job, employment (category 1) & 11.6 & 15.6 \\
\hline Financial prosperity, without debts (category 1) & 43.4 & 21.2 \\
\hline Leisure time spent together (category 3) & 22.7 & 13.8 \\
\hline Tolerance, help, support (category 2) & 18.2 & 9.1 \\
\hline $\begin{array}{l}\text { Harmonic relationships, emotional satisfaction, no } \\
\text { conflicts and tensions (category 3) }\end{array}$ & 36.5 & 56.8 \\
\hline Succesful children, education of children (category 1, 2) & 6.4 & 4.8 \\
\hline Complete family - both parents and children (category 2, 3) & 8.1 & 16.2 \\
\hline
\end{tabular}




\begin{tabular}{|l|l|l|}
\hline Like my family & 4.2 & 0.6 \\
\hline No image of a happy family & 1.6 & 0.3 \\
\hline Other answers & 1.4 & 0.8 \\
\hline
\end{tabular}

\subsubsection{Satisfaction with some aspects of spending of leisure time}

We have also asked our respondents, how much they are satisfied with their leisure time and family activities in leisure time.

Our data in both countries have showed that families were mostly satisfied with the quality of their leisure time during holidays and free time. Quantity of free time has been sufficient during weekends.

Table 3. Satisfaction of spending of leisure time (1-unsatisfied, 6-very satisfied).

\begin{tabular}{|c|c|c|c|c|}
\hline & \multicolumn{2}{|c|}{ Czech Republic } & \multicolumn{2}{|c|}{ Latvia } \\
\hline & Mean & $\begin{array}{c}\text { Std. } \\
\text { deviaton }\end{array}$ & Mean & $\begin{array}{c}\text { Std. } \\
\text { deviation }\end{array}$ \\
\hline $\begin{array}{l}\text { With the quantity of free time after } \\
\text { work }\end{array}$ & 4.03 & 1.514 & 4.35 & 1.428 \\
\hline $\begin{array}{l}\text { With the quantity of free time during } \\
\text { the weekend }\end{array}$ & 4.84 & 1.393 & 4.92 & 1.346 \\
\hline With the length of yearly leave & 4.64 & 1.587 & 4.92 & 1.475 \\
\hline $\begin{array}{l}\text { With the quality of rest which I get } \\
\text { during my holiday }\end{array}$ & 5.13 & 1.313 & 4.88 & 1.300 \\
\hline $\begin{array}{l}\text { With the quality of rest I have in my } \\
\text { free time }\end{array}$ & 4.78 & 1.276 & 4.99 & 1.188 \\
\hline $\begin{array}{l}\text { With the quality of free time which I } \\
\text { have for my hobbies }\end{array}$ & 4.06 & 1.534 & 4.80 & 1.449 \\
\hline $\begin{array}{l}\text { With the quantity of free time which I } \\
\text { can be with my loved ones }\end{array}$ & 4.40 & 1.451 & 4.72 & 1.581 \\
\hline With diversity of my free time & 4.40 & 1.456 & 4.74 & 1.372 \\
\hline
\end{tabular}

We tried to ask about differencies between both countries in the leisure time happines and satisfaction. We used a parametric and non-parametric test ( $t$-test, Mann-Whitney test) to test the significance of differencies between both countries. Data of these tests showed a significant differencies between both populations in their satisfaction related to free time.

Furthermore, we could observe a tendency of people in Latvia to be more satisfied with their leisure time in almost all items we asked about at the significant level (chi square sig. lower than 0.05).

\section{Conclusions}

We tried to study happines in family from different points of view. Firstly we focused on what is an image of a happy family for people living in families with children. Secondly we analysed questions related to the happines with activities in leisure time and spending of leisure time. We used a qualitative approach for the first topic and discovered four main 
categories which contributed to the feeling of being happy in family. In relation to the social and family policy, we tend to be persuaded about possibilites to support happy family life by different social means and tools.

Table 4. Differencies in satisfaction with free time in Czech and Latvian families.

\begin{tabular}{|l|c|c|}
\hline & T-test & $\begin{array}{c}\text { Mann- } \\
\text { Whitney }\end{array}$ \\
\cline { 2 - 3 } & Sig. & Sig. \\
\hline With the quantity of free time after work & 0.000 & 0.000 \\
\hline With the length of yearly leave & 0.003 & 0.002 \\
\hline With the quality of rest which I get during my holiday & 0.013 & 0.013 \\
\hline With the quality of rest which I get during my free time & 0.001 & 0.001 \\
\hline With the quantity of free time which I have for my hobbies & 0.000 & 0.000 \\
\hline With the quantity of free time which I can be with my loved ones & 0.000 & 0.000 \\
\hline With diversity of my free time & 0.000 & 0.000 \\
\hline
\end{tabular}

Second part, devoted to satisfaction with leisure time, showed a slight difference between both countries. Latvian respondents and families declared a higher satisfaction with their leisure time activities, but we have not found any important variable that could explain these results. It could be an inspiring topic for the next research.

As Latvians indicated more satisfaction with quantity and quality of free time in comparison with Czech people, after a time distance we compared our results with the results from the research done by the "Baltic International Bank Latvian Barometer" in October 2016.

Within the framework of the research respondents were asked to evaluate their satisfaction with life, to name things that give them a sense of happiness, and to describe their approach to setting goals of life. According to the results of the research, respondents more often evaluate their lives positively than critically. By describing aspects that could make them more satisfied with life, the most commonly reported participants were better health and more opportunity to earn. In between, things that are more enjoyable in life are often called spending time with the family (67\%). Also, in the answer to the question what they would most like to achieve, a happy family was most often mentioned [12].

From the research results it can be concluded, that family deserves a high value in people's mind despite the rapid changes in the family structure and high rate of divorce in de facto in both countries.

\section{References}

1. Dimitris Ballas1 and Mark Tranmer2. (2012). Happy People or Happy Places? A Multilevel Modeling Approach to the Analysis of Happiness and Well-Being. International Regional Science Review 35(1) 70-102 http: / / journals. sagepub.com.db.rsu.lv/doi/pdf/10.1177/0160017611403737

2. Kožený, J., Csémy, L., Tišanská, L. Strukturální analýza modelu životní spokojenosti adolescentů. Československá psychologie, 2007, 51, 3, p. 224-237 
3. Sobotková, I., Reiterová, E., Hurníková, K. Rozdíly mezi otci a matkami v pohledu na fungování rodiny, $\mathrm{v}$ životní spokojenosti a rovnováze mezi prací a rodinou. Československá psychologie, 2011, 55, 2, p. 139-151

4. Hamplová, D. Životní spokojenost, štěstí a rodinný stav v 21 evropských zemích (Life satisfaction, happiness and family status in the 21 European countries). Czech Sociological Review, 2006, 42, 1, p. 35-55

5. Hamplová, D. Životní spokojenost, štěstí a rodinný stav v 21 evropských zemích (Life satisfaction, happiness and family status in the 21 European countries). Czech Sociological Review, 2006, 42, 1, p. 43-52

6. World Happiness Report 2016. http://worldhappiness.report/wpcontent/uploads/sites/2/2016/03/HR-V1Ch2_web.pdf

7. Czech Demographic Handbook 2015. https://www.czso.cz/csu/ czso/czech-demographic-handbook-2015

8. Share of couples living in consensual union is growing. http: //www.csb.gov.lv/notikumi/pieaug-neregistretakopdzive-dzivojosu-paru-gimenu-ipatsvars39126.html\#_ftn1

9. Marriages and divorces. http://www.csb.gov.lv/statistikastemas/metodologija/noslegtas-un-skirtas-laulibas36799.html ?order=name\&sort=asc

10. Līga Āboliṇa Ģimene un tās atbalsta politikas attīstība Latvijā (1990-2015) Promocijas darbs., Rīga, 2016.42.lpp.

11. Cited from Lars-Göran Sund, Kosmas X. Smyrnios. Striving for Happiness and Its Impact on Family Stability: An Exploration of the Aristotelian Conception of Happiness. http://journals.sagepub.com.db.rsu.lv/doi/pdf/ $10.1111 / j .1741-6248.2005 .00038 . x$

12. Laime un dzīves mērķi. Baltic International Bank Latvijas barometrs (2016). https://www.bib.eu/uploads/2017/02/2016.11.Laime_dzives_ merki_Baltic_International_Bank_Latvijas_barometrs.pdf 
